\title{
Inclusive Urban Campus Development: A Case for Okahandja, Namibia
}

\author{
Sampson Umenne, Madelein Stoffberg, Laudika Kandjinga \\ Department of Architecture and Spatial Planning, Namibia University of Science and Technology (NUST), Windhoek, Namibia \\ Email: sikumenne@gmail.com, mstoffberg@nust.na, lkandjinga@nust.na
}

How to cite this paper: Umenne, S., Stoffberg, M. and Kandjinga, L. (2021) Inclusive Urban Campus Development: A Case for Okahandja, Namibia. Journal of Building Construction and Planning Research, 9, 231-250.

https://doi.org/10.4236/jbcpr.2021.94015

Received: July 2, 2021

Accepted: October 24, 2021

Published: October 27, 2021

Copyright $\odot 2021$ by author(s) and Scientific Research Publishing Inc. This work is licensed under the Creative Commons Attribution International License (CC BY 4.0).

http://creativecommons.org/licenses/by/4.0/

\begin{abstract}
As a result of the high rate of urbanization and the attendant growth in housing demand and proliferation of informal settlements in sub-Saharan African countries such as Namibia, the development of cities has become a priority concern of the governments given the obvious socio-economic and environmental challenges that impact sustainable infrastructure/services, quality of life, health and well-being of the citizenry as referenced in the United Nation Sustainable Development Goal (UN SDG) Number 11. Whereas the governments are conscious of these daunting challenges, they remain unable to decipher sustainable solutions to them. The consequence is the perennial proliferation of informal settlements, housing shortages, and urban poverty, pressure on infrastructure and services, and unemployment. Although dubbed a "Garden Town" Okahandja does not have an urban structure plan of development. This study aims to investigate the feasibility of socially inclusive urban infrastructure campus development using Okahandja as a platform. Recent research has revealed such trends as the smart city concept which embodies a sustainable approach to Inclusive Urban Campus (IUC) development towards a holistic community planning in third world countries. Dololo site in the south of Okahandja stands out as an opportune urban campus platform for diverse mixed-use including residential, business-related (entrepreneurial), educational, recreational, and others. The research employed a novel multi-focused workshop methodology for data collection with community engagement and stakeholders' interactive participation as a key strategy to enhance the bottom-up development approach. The objectives were to identify the town planning and integrated development dynamics of Okahandja, the policy bottlenecks, expose sustainable forms of socio-cultural integration and formal housing delivery. Ultimately, the feasibility of Dololo as a platform for the inclusive urban campus initiative was not in doubt. Infrastructural development and community need to accommodate education, Small and Medium Enterprise (SME), Vocational Training Center (VTC), in-
\end{abstract}


formal trade, housing, health, youth centers, cooperatives, roads, and transport are identified as key to the IUC development.

\section{Keywords}

Inclusive Urban Campus Development, Stakeholder Engagement, Housing, Sustainable Infrastructure

\section{Introduction}

One of the problems plaguing the process and management of development in third-world urban settlements is undoubtedly the unregulated rapid pace of urbanization. Namibia is not an exception from this inevitable outcome of rural-urban migration. This urbanization phenomenon results in the population drift from rural to urban areas with the high demographic surge, the decrease in the proportion of people living in rural areas, and adverse impact as societies make desperate efforts to adapt to this change. Whereas urbanization may have some positive tenets such as the modernization of lifestyle, its inevitable acceleration through globalization poses immense challenges for sustainable urban development, especially for weak economies like Namibia. Some of the key challenges include high urban population density resulting in unbearable pressure on the existing meager services and infrastructure, the shortfall in affordable housing, the proliferation of urban informality and slums, high youth unemployment, to mention but a few. The unduly rapid destabilization of society's cultural equilibrium, especially in the urbanized settlements falls out of the scope of this research.

In Namibia, within the period 2009-2019, the urbanization rate grew from $40.6 \%-51.04 \%$ [1]. Around this period, the research consortium from the University of Tampere (UTA) Finland, visited the Namibia University of Science and Technology (NUST) and brought with it the Smart Community (SmartCom) concept intended to amongst others proffer a solution to the daunting housing backlog in Namibia in step with the Harambee Prosperity Plan (HPP) initiative of Government and the United Nation Sustainable Development Goals (UN SDG) matrix. The other good intentions were to enhance public services, improve city management, reduce costs, and improve quality of life, but the technology involved was found to be out of sync with the immediate needs and issues of communities. Indeed, many such initiatives to improve public services should be such which have a direct impact on the daily lives of the community. Examples include improved waste management, open spaces' planning, efficient public transportation, household energy management, health, and education infrastructure. The initial target communities of SmartCom were those of Keetmanshoop and Ondangwa towns. To make a meaningful shift in the initial co-creation of the SmartCom concept for the development of Namibian towns, the need to foster a research partnership between the UTA and the NUST was 
conceived. Under the UTA-NUST Partnership Service Agreement, the urban development research initiative was focused on the feasibility study of Okahandja "Garden" Town as a testing ground for the concept of an IUC development. The IUC was conceived as a strategy to host diverse land-use urban activities for enhanced integrated services to the urban communities. In the specific case of the Dololo platform, it implies the comprehensive design and development of an urban campus entity within which diverse housing models, community institutions, recreational and commercial enterprises, can be established to coexist, and impactfully serve the communities. It stands to be an innovative approach to urban land use in Namibia's urban centers to stimulate growth and improve the living standards of the urbanites inclusively.

\subsection{Study Site}

The study site, referred to as Dololo, was volunteered by a public partnership group keen to contribute to the research task. Dololo is 86 ha of land, centrally located and only 30 minutes ride north of the capital city Windhoek and $10 \mathrm{~km}$ south of Okahandja town (Figure 1 and Figure 2). It is situated between the B1 and A1 highways, directly adjacent to two fiber optic lines, water, and power supply infrastructure, and the railway line (Figure 3). The platform embodies the territory within the townlands of the Okahandja Municipality, making it an integral part of the town's spatial development in terms of its contribution to the town's spatial design, physical, functional, and management [2]. It is adjacent to the newly developed Osona Village housing project-a very popular housing estate for the low and middle-income workers who commute to and from Windhoek daily.

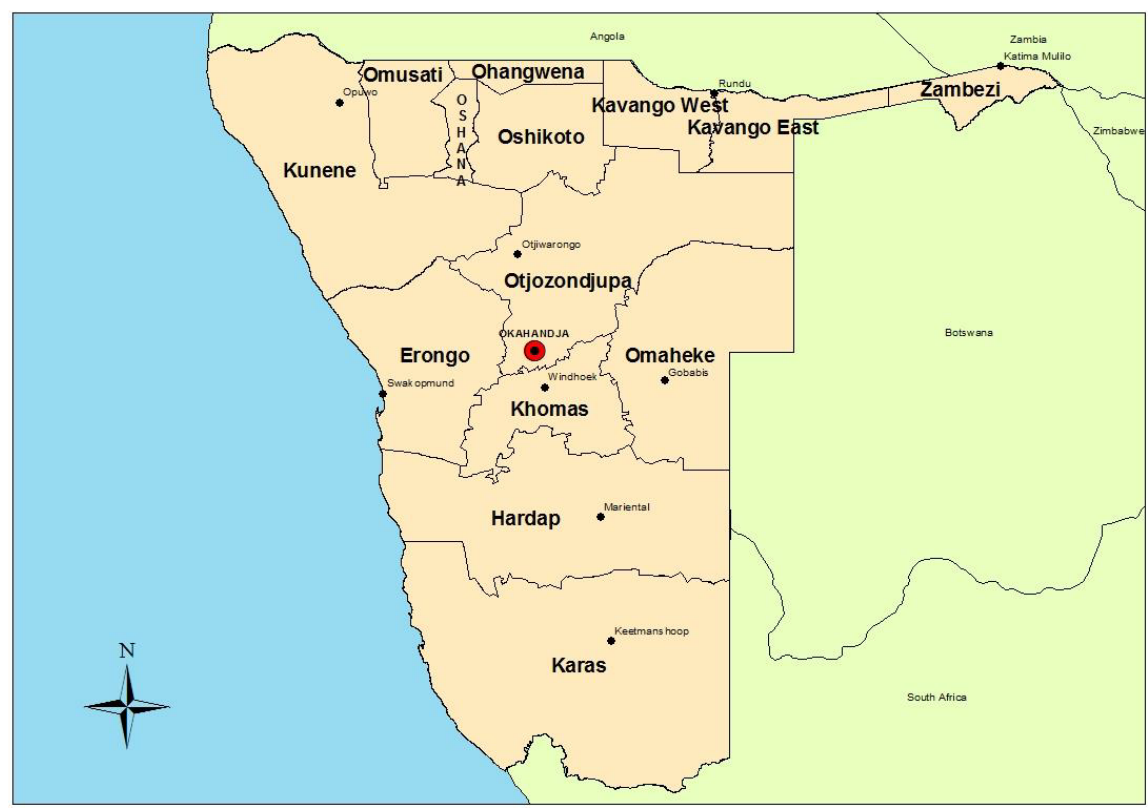

Figure 1. Location of Okahandja Town in the Otjozondjupa Region. Sources: Africa Planning Forum (2015). 


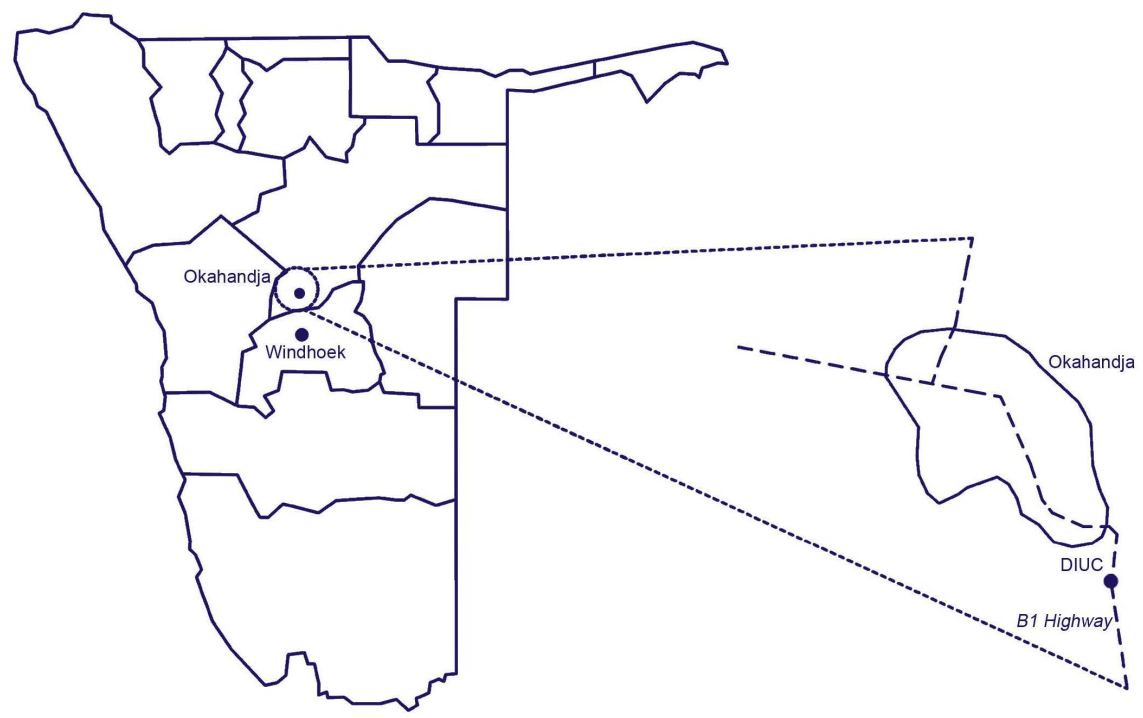

Figure 2. Location of Dololo site within the Okahandja Townland. Source: Research Team Poster (2019).

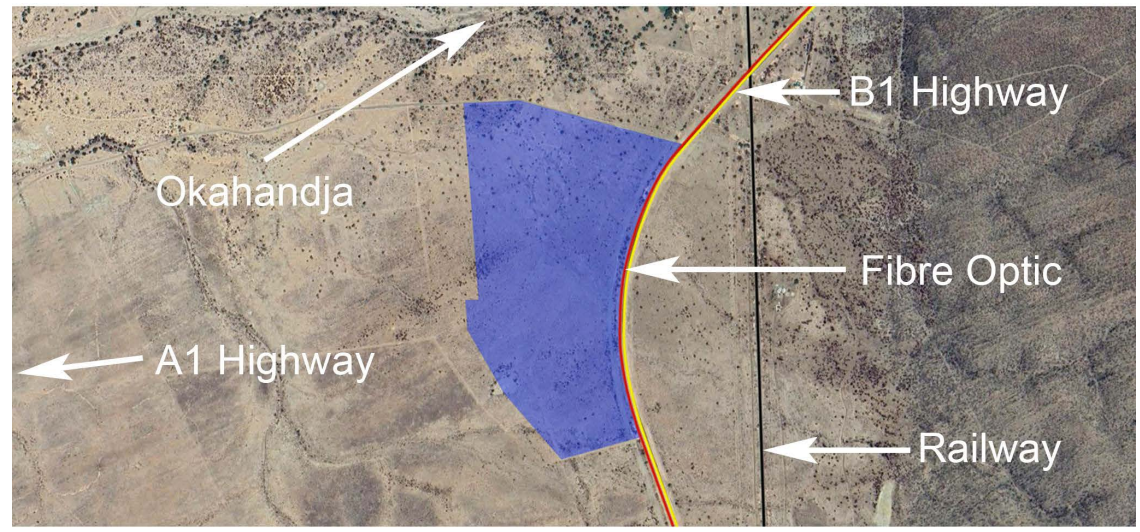

Figure 3. Dololo site. Source: Research Team, 2019.

Although "Dololo" literarily means "nothing" in one of the local languages, the Dololo project site is envisaged to provide a singular opportunity for an inclusive urban infrastructure hub-the first of its type in Namibian development practice. It is envisaged to encourage a new approach to urban land use in $\mathrm{Na}$ mibia, capable of stimulating entrepreneurship and job creation and contributing to the towns' knowledge economy. Namibia'sfascinating landscape (Figure 4) yawns for a model land-use appropriate for a "garden" town.

All these recommend the Dololo site as a suitable landmass for the IUC research and pilot implementation. Furthermore, the town and IUC infrastructure will complement each other in many aspects as they mutually contribute to the production of knowledge economy due to the interactions and links with private sectors and industries [2] [3] [4]. Thus, the Dololo site came in handy as an opportune platform to host the integrated diverse land-use activities through the IUC paradigm. As a concept, the IUC is globally popular due to its inclusive, integrated approach unlike some of the urban campuses in common practice such 


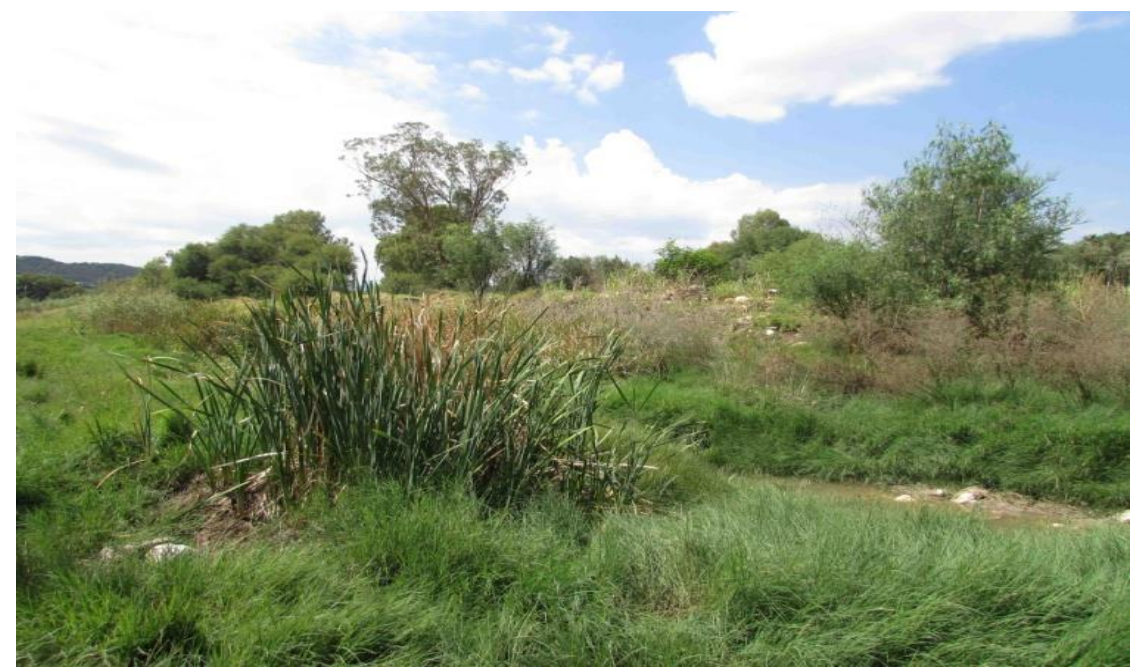

Figure 4. Landscape feature of the project site. Source: Research Team, 2019.

as the University of Stellenbosch in South Africa that is confined to core commercial function. As envisaged in the case of Okahandja, the IUC should include mixed residential complexes, tourism-related retail and leisure, education and research, health and culture infrastructure services. The inclusion and connectivity (the connection between the different urban activities) were some of the key points discussed during the stakeholder engagement meetings, under workshopping sessions. In general, the proposed inclusive urban campus initiative is expected to create synergies with the existing town infrastructure layout within the boundaries of Okahandja including the recent Osona Village Development, adjacent to the project site.

\subsection{Contextual Discussion}

As stated above, one of the key problems this research attempts to address is access to affordable decent housing for the poor who in large numbers leave their rural homes and are obliged to reside in urban ghettos and makeshift homes and shacks. Besides, the low and middle-income contingents of the urban population find it very unaffordable to provide their families with decent homes. The problem of unemployment especially that of the youths is also under the investigative radii of this research. According to the Namibia Country Report of the Government of the Republic of Namibia, for the Third United Nations (UN) Conference on Housing and Sustainable Urban Development (Habitat III) (2015), one challenge facing the country towards Vision 2030 is the management of urban growth, largely due to unregulated rapid urbanization. According to the Report, successful urban growth management is sine-qua-non for inclusive growth, sustainable housing for the poor, and improved service delivery for a healthy and productive urban population. To this end, an articulate urban development strategy must be coined up to enhance socially integrated and economically inclusive human settlement development. Accordingly, this research aims to explore the feasibility of the IUC concept towards the achievement of the 
urban growth management objectives using the Dololo site as a strategic platform.

The garden town name for Okahandja may have been a fun version of the Ebenezer Howard Garden city movement of 1898. This is understandable from the viewpoint of a town founded in 1800 at the confluence of two rivers, which largely determine the Okahandja town's ecological setting with prospects to emerge as a green town. As history has it, "Okahandja" in Otjiherero means "the place where two rivers flow into each other to form one wide one". Suffice it to state that this research equally aims to develop an IUC which is environmentally sustainable.

According to [5], in developing countries with a high rate of rural-urban migration, it is commonplace to have a concentration of economic activities in a few urban centers. As such, population migration becomes the single option for both the skilled and the unskilled in their quest to benefit from the scarce opportunities for livelihood. Unfortunately, the land use planning for housing, built structures for the economic, educational, and recreational activities, as well as infrastructure services, historically failed to consider an inclusive approach. It is, therefore, the goal of this research to develop and promote the IUC concept as an integrated approach that can bring together in one urban land-use platform sustainable, accessible and affordable solutions to challenges faced by urban communities in the context of uncontrollable urbanization syndrome (Figure 5).

\subsection{Urban Context in Namibia}

Urban areas are centers for social interaction, economic advancement and offer copious opportunities and need fulfillments. Some are dominant political, administrative, and cultural centers. This often results in people being attracted to urban centers, which is a misconception, as more people in urban areas are

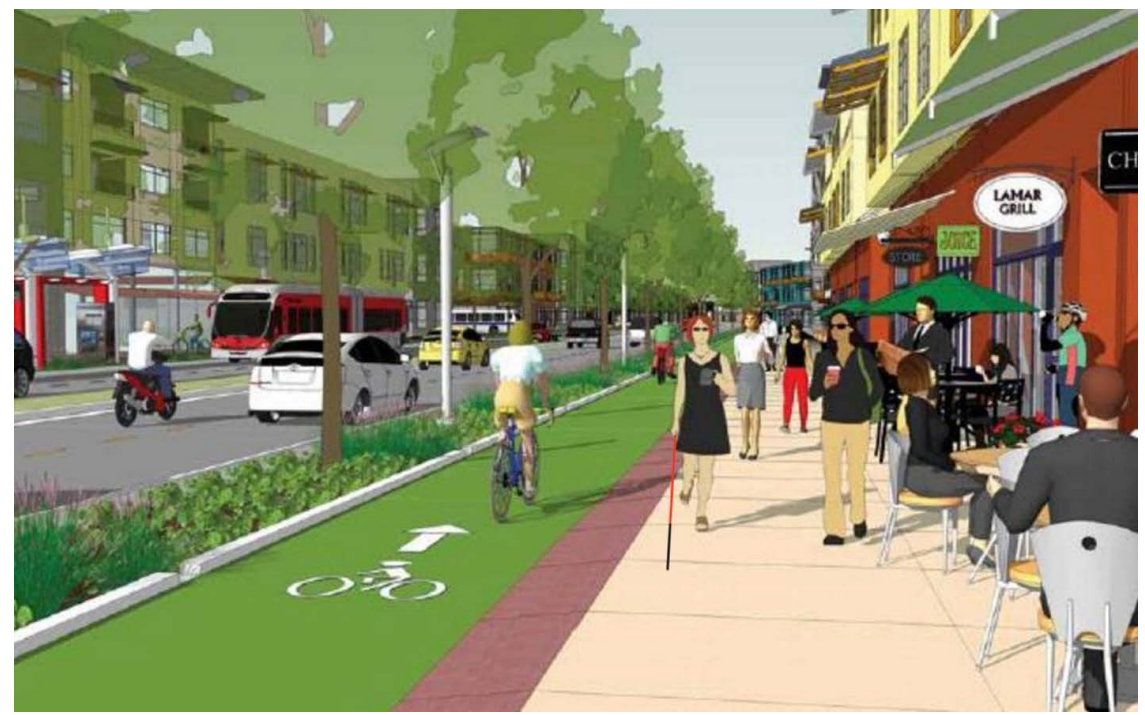

Figure 5. A 3-D model of inclusive urban design. Source: Darren Bates, 2017. 
trapped in poverty than in some rural areas. Urban centers are seen as the catalyst for development [5]. However, the rural-urban linkage is also essential for the development of the country. Often people see urban and rural areas as independent entities. These two are interdependent and interlinked leading to a constant flow of reasons between them. Many people in urban centers "maintain strong social and economic links with their rural areas of origin" [6].

In Namibia, urban context history dated back to the apartheid regime, which influenced the country's spatial issues. The apartheid policy on planning and development left Namibia and Windhoek, particularly with long-lasting scars of the structure and spatial nature of its urban environment [7] and other current socio-economic conditions. Reference [7] claim that the distinction between the former privileged areas and townships in urban centers exists and evidently, particularly the socio-economic conditions. For instance, in Windhoek, people are segregated based on ethnicity and race. Before independence in 1990 from the Apartheid regime, people's movement was restricted [8]. After independence, the constitution guarantees any person's right to "reside and settle in any part of Namibia" [9]. This opens people's movements; subsequently, urban centers began experiencing an influx of people searching for better social and economic opportunities. Consequently, many other urban centers have since then been proclaimed in the country. Namibia has hierarchies of urban centers as follows: Part 1 municipalities, Part 2 municipalities, and town councils and village councils established under the Local Authority Act, No. 23 of 1992. This Act defines the power and duties of each urban center within its respective jurisdictions.

Many people in urban centers, particularly in the main urban centers-Windhoek, Walvis Bay, Okahandja, and others, have families and houses in rural areas. They are in urban centers looking for economic opportunities and some have houses bought through the banks-arrangements applicable only to urban centers. Unsurprising, the urban population is relatively young compared to the rural area population, which is growing older. On the contrary, some commute to these towns from and to Windhoek for various reasons. These commuters reside in these towns where they have houses or renting, much cheaper than in Windhoek. This situation led to several research and calls, such as sustainable urban transport master plan between these towns, smart cities' needs, and mixed development. Similarly, other towns experience socio-economic conditions and other challenges. The central issues common to urban centers include inadequate and unaffordable housing and serviced land, contributing to the mushrooming of informal settlements, poverty, high unemployment, and inequality. These issues vary depending on the urban centers.

Urban centers in Namibia are characterized by disparities and unbalanced spatial development. These disparities can be attributed to several factors such as the absence of spatial plans to guide development and the slow pace of decentralization as per the Decentralization Policy of 1998 and Decentralization Enabling Act 33 of 2000. The poverty level in urban areas has also increased over the 
years, necessitating the government to introduce the Food Bank Program in 2015. The program was rolled out in Windhoek and subsequently to other selected urban centers.

\subsection{Urban Development and Housing Policies in Namibia}

Reference [10] indicated that about $49.9 \%$ of Namibia's population lives in urban areas; about $50.1 \%$ in rural areas. This shows a new trend due to migration patterns. The government has also recognized urban centers as "a cost-effective way of making investments and supplying services" [6] due to the concentration of people. This has adverse effects on migration and encourages imbalance in spatial development, further compounded by the slow pace of decentralization. Urban development in Namibia lies with the Ministry of Urban and Rural Development but other actors and sectors are equally essential in ensuring agglomeration activities and functions.

Some of the spatial planning problems faced are attributed to the previous urban planning and proclamation process, which were described as outdated, cumbersome, and slow, resulting in the inflation of development cost and high cost of erven (serviced land) [11]. Until 2020, the town planning processes, including land delivery, were governed by the Town Planning Ordinance, 18 of 1954, and Township and Land Ordinance, 11 of 1963. A process of land delivery would take between 28 - 42 months or even more. However, the recent Urban and Regional Planning Act, No. 5 of 2018, which replaced the two ordinances only came into force in 2020, is anticipated to address unbalanced spatial development and land delivery issues. Instead of the two bodies, namely the Namibia Planning Advisory Board (NAMPAB) and Township Board, to deal with matters separately, the Act established the Urban and Regional Planning Board to address the issues simultaneously. The Act aims to deal with spatial planning issues in the country, such as to ensure uniformity and integrated regulatory framework, to decentralize some aspects of spatial planning to regional and town councils, to promote social and economic inclusion in all spatial planning related plans and activities, and to redress previous imbalances related to matters associated with access and ownership of land. Additionally, it provides for the national spatial development framework, regional structure plan, and urban structure plan. The anticipation is for all the regions and urban centers to have structure plans to guide spatial development within their respective jurisdictions. Once these spatial instruments are established and enforced, this would ensure equity, balanced development, social inclusivity, and fast-track land delivery and services.

Land delivery, and more so serviced land and housing, have been concerns and require urgent interventions. It is governed and supported by various legislation and policies such as Namibia National Housing Policy of 1991 (revised in 2009), Local Authority Act 23 of 1992, National Housing Enterprise Act 5 of 1993, Vision 2030, Flexible Land Tenure Act 4 of 2012, HPP and Urban and Re- 
gional Planning Act. However, the central policy on housing is the Namibia National Housing Policy which states that municipal service infrastructure and housing are interlinked as they complement each other [11]. The inadequate investments in the urban infrastructure had effects on serviced land delivery and housing. The policy provides a framework and environment for actors to execute housing development. It aims to promote sustainable human settlements, with more emphasis on integrating housing development designs. Additionally, it states that housing delivery should increase the number of units while at the same time ensuring sustainable human settlement.

It further emphasised the need for an integrated approach wherever specific land-use activities (schools, health facilities, commercial services, housing, and other amenities) are developed and regarded as part of the same development. Similarly, any new housing initiatives and urban settlements' development be integrated [12] into the respective town's existing and planned spatial development in Okahandja. Despite several urban development policies and programmes, housing remains a key challenge. In October 2013, the national housing backlog stood at 100,000 housing units, with an annual increase of 3700 units $^{1}$, mainly in Windhoek. This figure has increased from 80,000 housing units estimated in 2004 in the National Vision 2030 [12]. The national housing backlog is likely to have escalated over the years. Similarly, it appears that there are no segregated statistics for individual towns such as Okahandja. Each local authority and Namibia Housing Enterprise-mandated to deliver housing countrywide have a sizeable waiting list of people wanting residential erven. Over the past years, several housing programs and initiatives have been implemented; however, housing remains a challenge and needs to be addressed to reduce the backlog.

Due to technical and procedural reasons, the central government placed a land moratorium on the Okahandja Municipality between 2015 and 2020. This has affected the town's spatial development, including land delivery within its jurisdictions, and contributed further to informal settlements and land grabbing attempts. The growing demand for housing countrywide and Okahandja led to Osona Village housing project, which started in 2014, developed by the Preferred Management Services with funding from the Government Institutions Pension Fund of Namibia (GIPF). The village comprises diverse land uses, mainly residential. However, the demand for serviced land, housing, and infrastructure continues to grow and calls for partnerships between public, private, and communities to address these challenges. One such approach is the IUC development concept, which is entrenched in an integrated and inclusive approach.

\subsection{Inclusive Urban Campus Development Approach}

Sustainable development of urban spaces and resources has been the subject of discussion for some time. Global communities have recognized the need to use urban space optimally. Consequently, several concepts have been adopted: sus-

${ }^{1}$ Based on the summary of blueprint on Mass Housing Development initiative in Namibia. 
tainability, smart growth, compact and new urbanism, to mention a few. A remedy to unsustainable planning and urban spaces development is pursued, and consequently, the inclusive urban development paradigm.

Reference [13] 12 distinguished between perspectives of inclusive development: 1) "content of development" in general 2) addressing people's needs, particularly the disadvantaged and marginalized individuals, 3) focusing solely on the socio-economic aspects and qualities while others perceived it to focus on social and relational or political inclusiveness. Inclusive growth or development has been mainly entrenched to address inequality [14]. Developing countries have high inequality, and Namibia has been one of the countries with high inequality [15]. Besides, disparities exist at both national and regional levels. The imbalances in the distribution of essential services, facilities, and infrastructure are common, contributing to urbanization and putting pressure on existing services and facilities in the urban settlements.

Given the broadness of the IUC concept, several instruments, approaches, policies are adopted to advocate it to address socio-economic conditions such as inadequate services and facilities, job creations, and essential needs [14]. In this context, IUC development means the distribution and allocation of land-uses or human activities and services within a confirmed urban space to benefit the target groups.

IUC development is envisioned to be an educational hub that comprises other land uses and activities. The inclusive education hub is gaining momentum as a "campus of tomorrow" [16]. IUC does not aim to provide physical education facilities and houses, creating a platform to host diverse land-use activities. It seeks to assemble copious compatible and complementary land-use activities in smart mixed-use development. IUC offers many advantages over the traditional educational campus development, providing services and activities under one umbrella, agglomerated and densified.

IUC concept implies that communities need to live close to working places and interact socially hence mixed-use development. This approach relates to smart community and urbanism concepts. Inclusive development offers some benefits, such as activity support, thereby creating natural surveillance to discourage criminal activities. The town, educational facilities, infrastructure, and entrepreneurship, are essential and mutually contributing to the production of knowledge economy due to the interactions and links with private sectors and industries [2] [3] [4]. Similarly, housing is equally essential as a component of the IUC paradigm.

This paper's focus is delimited to the needs for housing, education, and entrepreneurship. However, these activities do not exist in isolation but are strengthened by the presence of diverse infrastructure. It is not surprising that during the stakeholder consultations, housing emerged as one of the critical priorities of IUC, confirming the fact that housing is primary need for humankind, yet unaffordable to many, particularly in developing countries. Most developing coun- 
tries are characterized by inadequate and unaffordable housing. Namibia is no exception to this crisis.

\section{Methodology}

The case study of Dololo as a platform for an IUC required a transdisciplinary approach that could bridge the gap between practice and policy [17]. By following a transdisciplinary approach, non-academics could be involved in the co-production of a solution that focuses on inclusion, collaboration, integration, usability, and reflexivity [18]. Transdisciplinary research taps into the knowledge of different parastatals to ensure that transformative knowledge could be generated resulting in societal change. Therefore, stakeholders that would be involved in the implementation thereof should also be included to ensure that research is feasible and applicable to current approaches. Through this multi-stakeholder approach, the co-production of knowledge was harnessed to investigate and propose solutions for the Dololo platform. From the identified stakeholder's community, experts and decision-makers were identified to provide sustainable solutions that address SDG 11 from a community perspective. This approach is critical to move beyond disciplinary boundaries, to link knowledge to practice and everyday life application [19].

This approach necessitated the organization of two workshops, with the aim of the first workshop to co-produce knowledge and the second workshop to co-design and explore possible solutions for the IUC. Both workshops were held in the Okahandja town hall to ensure participation from the specific region and allow enough space for interactive participation. These multi-stakeholder engagements had to be flexible and interactive, allowing participants from diverse backgrounds to understand and relate to the approach and methods applied. Identification of key stakeholders was critical in the organization of these workshops to ensure a broad representation of the community, policymakers, implementers, and prospective investors or partners. Initial stakeholder mapping completed by the research team assisted with the identification of key participants for the first workshop. During the first workshop, participants contributed to the stakeholder map to add to the initial list of stakeholders.

To ensure effective engagement with the broad representation of community members and stakeholders, participatory methods were considered. Furthermore, participatory methods could ensure that a bottom-up approach is followed to include the community in the co-production of knowledge. As suggested by [20], this practice or method seeks to find common ground to build solutions that consider both policies, practical implementation, and everyday needs. Through participatory methods, spatial, infrastructure, socio-economic, zoning, community needs, ecological and future development plans could be identified in Okahandja and the surrounding area.

The first workshop aimed to involve the community in identifying preferred areas of urban development intervention and the possible impact thereof on 
their livelihood. To gather the data, focus groups were organized around interactive activities such as mapping and structured discussions. Through mapping, participants identified the areas where they lived and worked to familiarize and orientate themselves with the map. In addition, they also identified areas of opportunity, future development, and priority. These areas were indicated with different keys on the base map provided to participants (Figure 6).

Structured discussions allowed participants to further investigate their needs related to policy, culture, politics, and economy (Figure 7). This method allowed participants to comfortably share their ideas and to elaborate on points mentioned by fellow participants.

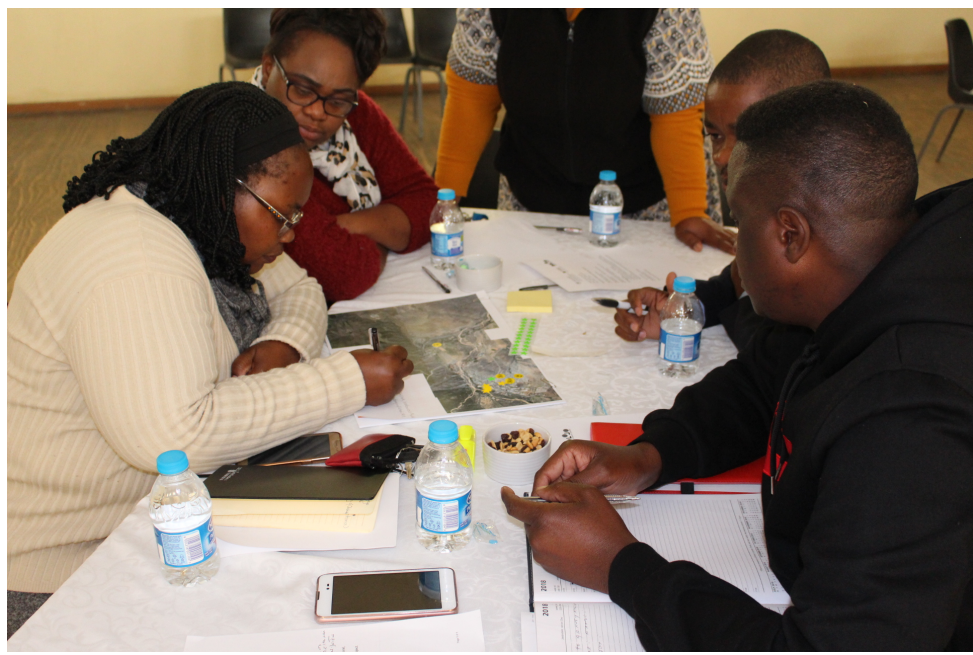

Figure 6. A group of stakeholders indicating areas of opportunity and development on a map of Okahandja and the immediate surroundings. Source: Research Team, 2019.

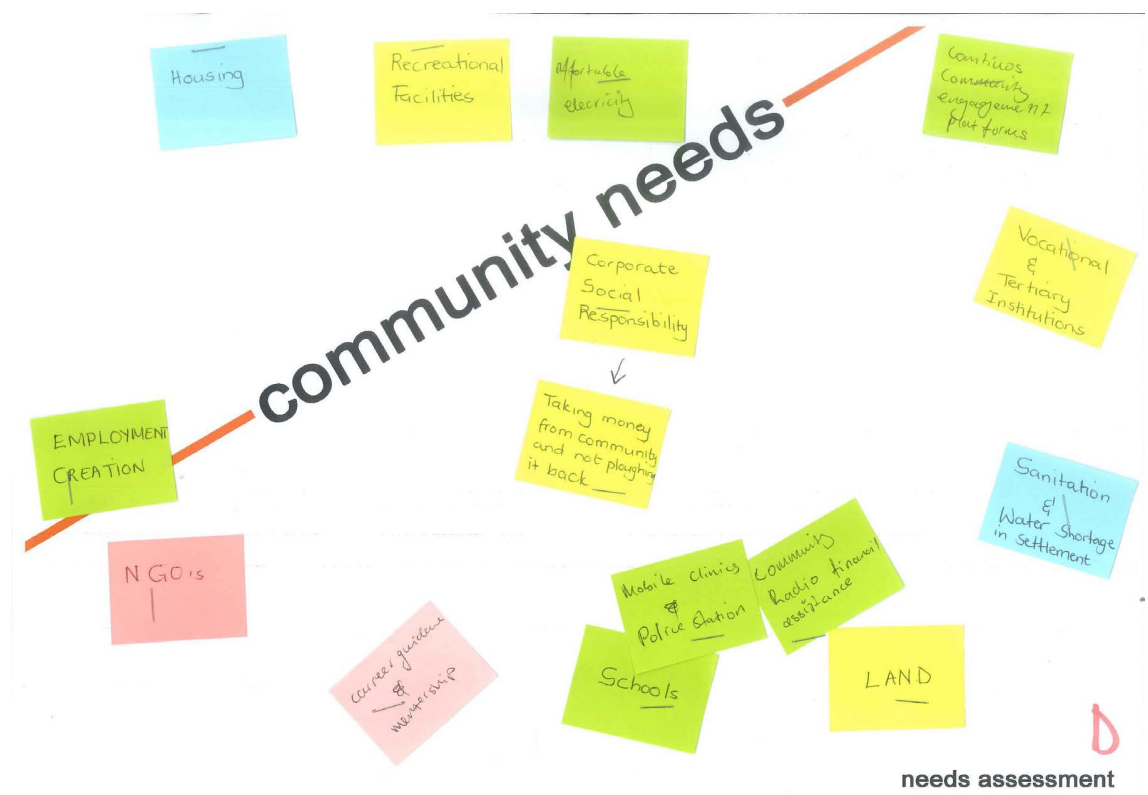

Figure 7. Identification of community needs by the identified stakeholders. Source: Research Team, 2019. 
After the needs and possible areas of spatial intervention were identified, a second workshop was necessary to further develop these ideas. Again, a transdisciplinary approach was used involving stakeholders from academia, students, built environment professionals, community members, the municipality, religious institutions, NGO's, and other relevant parties. As stated earlier, the aim of this workshop was to involve stakeholders in the co-design and co-production of the IUC. Through a presentation, stakeholders were informed on the meaning of an IUC, and how PP could contribute to the Dololo platform. Sort-charts, a game-board, and focus groups were utilized to start to guide the discussions around space, needs, and possible interventions.

Sort-chart is a useful method to facilitate participatory methods, organize data and to form associations between concepts, especially in cases where participants might not be knowledgeable of the subject language [21]. Sort-chart (categorization of images) was used to identify associations made between images and themes such as pedestrian, a vehicular flow, space of transition, exchange, connectivity, access, form and style, human scale and size, urban furniture, and setting.

Through the interactive game-board activity, participants were able to connect identified needs with the aims and objectives of the project as well as stakeholders that might benefit or contribute to the provision of certain amenities (Figure 8). The focus group was organized around images where participants (Figure 9) could discuss the requirements of the proposed IUC to address issues such as spatial organization, access, ownership, education, social space, living, community, commercial activity, and nature (ecology). Game-boards are used to create scenarios, relate to spatial conditions while considering the different stakeholders involved in the process [22].

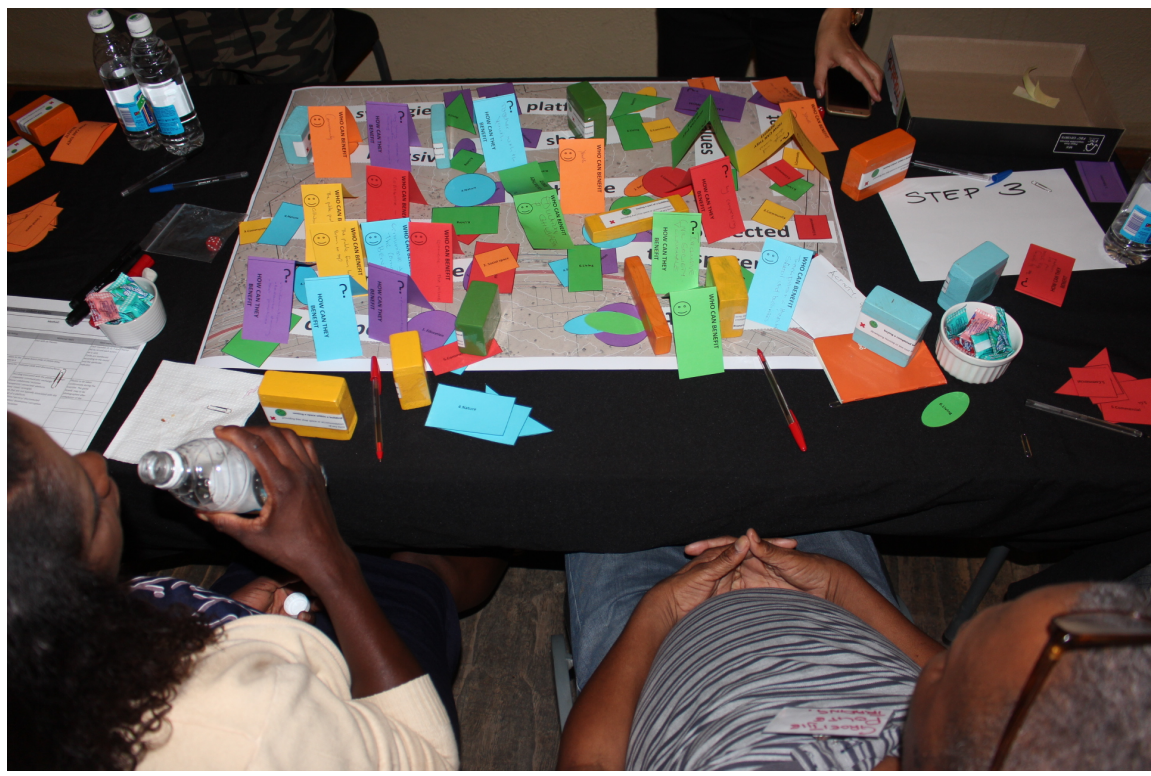

Figure 8. Identification of associations made between the IUC concept, function, and community needs. Source: Research Team, 2019. 


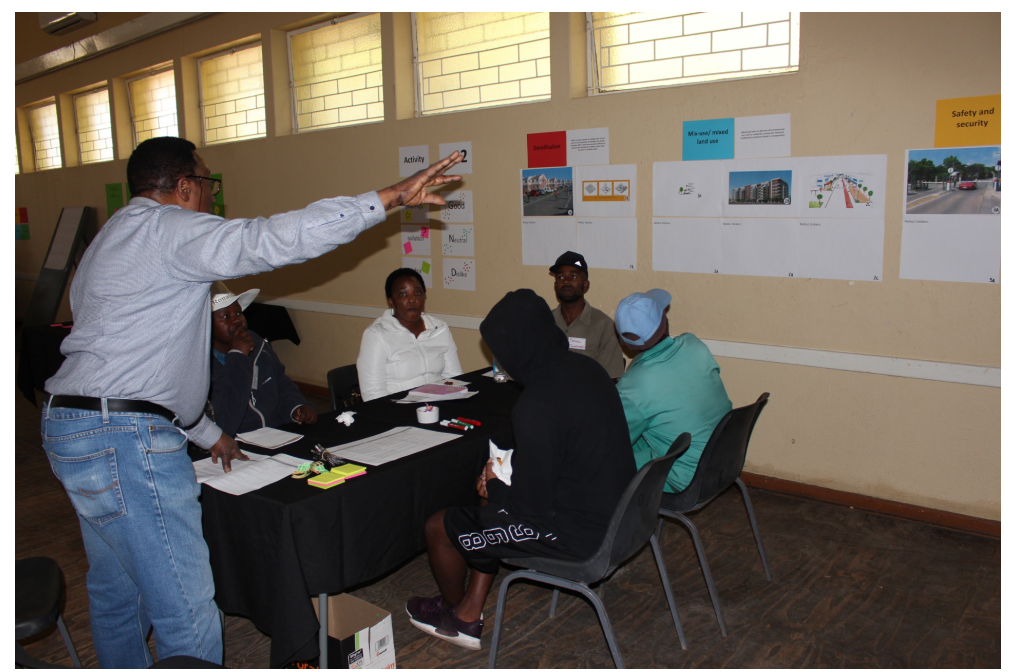

Figure 9. Focus group discussions to develop ideas around the spatial and functional requirements of the proposed IUC. Source: Research Team, 2019.

Thematic analysis of the data was applied to ensure that all identified aspects were considered in the proposed IUC concept. Data from the mapping and gameboard exercises were organized according to the predetermined themes to identify spatial needs, appropriate architectural solutions and to identify socio-economic conditions to evaluate the feasibility of an IUC.

\section{Results and Discussion}

The concept of Dololo as a platform for an IUC was introduced to community members through participatory methods, which has been deemed necessary to ensure sustainable development of proposed projects. The importance of community involvement has been noted by [23] and [24] to guide policy development and to ensure inclusive sustainable development.

Results from the gameboard indicated how participants understood this concept of an IUC development. Participants associated the IUC platform with terms such as values, meet, inclusive, collaborate, share, exchange, competition, communicate, synergies, cooperate, transparent, and connected. These terms (Figure 10) were then further discussed to indicate what spaces or functions are related to the terms.

The housing shortages in Namibia, and specifically in the Khomas region were noted by participants. They provided valuable information on housing needs to support the existing housing infrastructure provided in Okahandja and the Osona Village. Two housing typologies have been identified, low-income housing that is leased for below $\$ 203^{2}$ or with the option to buy below $\$ 20,298$ and middle-income housing that is leased for above $\$ 812$ per month. According to data collected, these housing typologies should mainly consist of three-bedroom townhouses with sufficient outdoor space suitable for gardening or urban agriculture. Although participants were aware of the cost implications of 3-bedroom ${ }^{2}$ Currency converted $\$ 1$ to N\$14.78 as on 22 September 2021. 


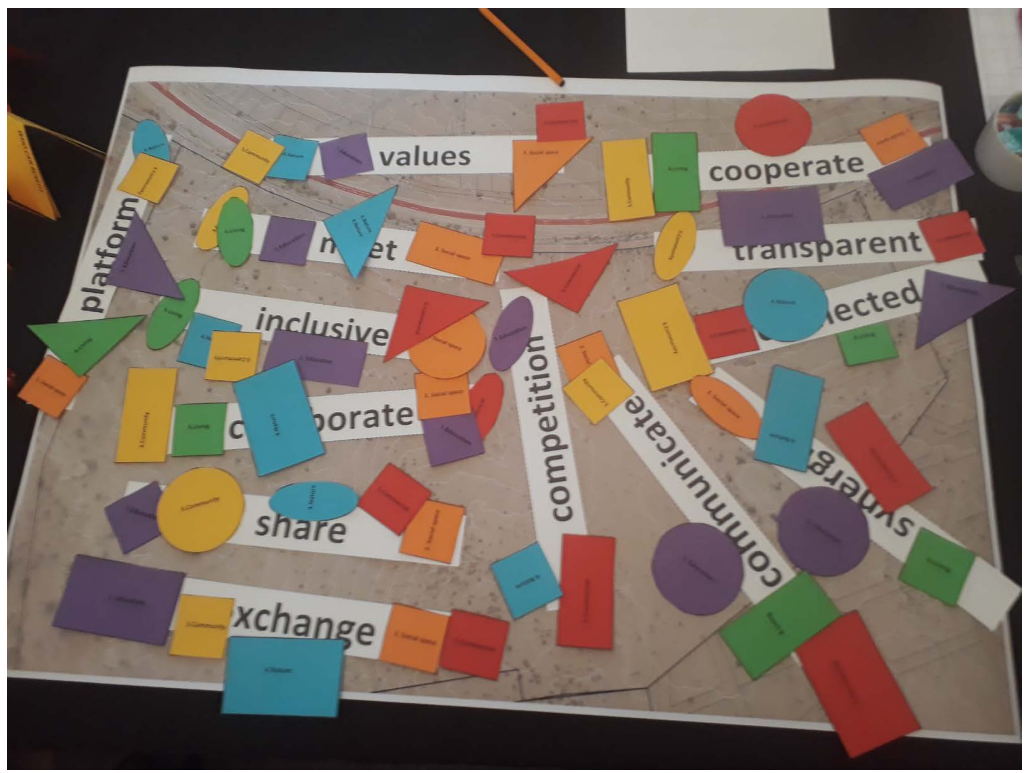

Figure 10. Gameboard method to explore the association participants made between the Dololo IUC platform and possible functions. Source: Research Team, 2019.

apartments, erfs with allowance for urban gardening and outdoor space, those needs were regarded as minimum requirements. The fact of the expressed dislike for one-bedroom apartments could be interpreted variously. One interpretation is that under the harsh conditions of high urbanization rate and poor resources, most families manage to cope with the tight makeshift residential conditions of the informal areas. However, if given the opportunity, they are clear and resolute in their needs for improved family livelihood. The need for student housing was also identified to accommodate learners from other regions of Namibia. In addition, community needs were also identified such as adjacent granny flats to enable residents to take care of extended family members or the elderly. The need for communal areas or designated playgrounds for children within settlements was also identified.

To finance the concept of an IUC, Public-Private Partnerships (PPP) are necessary for the most cost-effective solutions to finance and manage the development of urban settlements. This is one of the strategies already employed by the municipality to assist in the provision of housing and formalization of informal settlements as the case has been at the Osona village. The proposed IUC should include socio-economic support in the form of job creation, skills development, and commercial opportunities. Educational or institutional functions are supported by various amenities such as recreational, religious, and most important housing for various income groups. In addition to the provision of functions, participants also investigated the quality and nature of public spaces to be provided.

Participants argue that educational or institutional functions need to be supported by various amenities such as recreational, religious, and most important housing for various income groups. In addition to the provision of functions, 
participants also suggested the need for quality, well-functioning and maintained communal spaces such as public open spaces. Public open spaces provide relaxation, socializing, safety and social bond, including passive and active engagements. In addition, the communal spaces need to be equipped with sculptures or art and facades that create a relationship between internal and public spaces. For IUC to attain its intended purposes, the need for diverse infrastructure development is essential. The main prominent infrastructure suggested were housing development, education, vocational training, and those critical for entrepreneurship and business activities. The educational facilities need to provide a conducive environment for learning, youth development and opportunities to address unemployment. These are in addition to the urban infrastructure and services that are often provided during land servicing.

A sustainable approach to address SDG 11 is crucial and could be achieved by providing sustainable housing that focuses on environmental issues, socio-economic opportunities to provide more job opportunities for the unemployed, and alternative housing typologies that can be constructed on smaller erven. However, participants indicated that the minimum erf size of $300 \mathrm{~m}^{2}$ (as per Section 1 (iv) of the Townships and Division of Land Ordinance, 1963 (Ordinance 11 of 1963) is not adequate, although it is more affordable. Participants did not consider a $300 \mathrm{~m}^{2}$ erf to be appropriate for urban agriculture or enough space for children to play. High rise and densification were not considered as appropriate housing solutions within the given context. Respondents indicated that they rather prefer $700 \mathrm{~m}^{2}$ erven to provide more opportunity for urban agriculture and garden spaces. For the IUC, sustainability should be considered from multi-perspectives to include environmental concerns, construction, and provision of material for the built fabric, but most important to address the socio-economic viability of the proposed campus. Within the given context, the Dololo site is wedged between the Osona Village and Okahandja, enroot to Windhoek from Swakopmund. This location is ideal to provide a platform for alternative spatial solutions that incorporate mix-used buildings for both the education and corporate sector, while community functions support everyday life. The need for flexible spaces has been emphasized by the restrictions brought on by the Covid 19 virus, rendering traditional education and commercial office spaces obsolete, necessitating flexible space that accommodates remote learning or social distancing within office spaces. The proposed framework should support socio-economic opportunities by considering both the formal and informal sectors. The opportunities allow for the economic development of all sectors. Several examples were suggested, particularly the Post Mall Street located in the Windhoek's business district center, where formal and informal economic activities are found. In many developing countries, particularly in Africa, informal economic activities assist the inhabitants in addressing the severe socio-economic conditions [25], such as poverty, unemployment in the formal sectors. Often informal sector is neglected when accounting for the contribution to the country's economy, such as GDP; however, many people rely on it for survival. Relatedly, 
support for SMEs and start-up capitals need to be encouraged and supported to involve the youth in the Dololo platform.

Development through PPP's as seen in Elisenheim on the outskirts of Windhoek and Osona Village bordering Okahandja, provide much-needed solutions for the housing crises in Namibia. However, proposed infrastructural frameworks prescribe incremental development of economic, leisure, and educational facilities. The Goreangab Dam Waterfront and mix use development is a similar urban development project designed to provide Windhoek population the much-needed residential stands of varied densities and supporting amenities, amongst other infrastructures. These developments mostly focus on service provision and housing, with areas or zones earmarked for auxiliary functions. As a result of this incremental approach, these facilities are often not constructed due to financial constraints. In the case of the Goreangab Dam, surrounded by low-income low density residential developments, approved, and subsidized by the City of Windhoek, the potential for successful implementation is high. Currently, these developments lack the infrastructure to support socio-economic activities and education, which is critical to foster and create a sense of community. To exasperate the situation, gated communities are mostly peripheral with little access to the above-mentioned amenities. Therefore, the IUC approach emphasizes the development of platforms that foster the development of economic and educational facilities parallel with housing solutions. These platforms intend to provide the foundation for PPPs to establish start-up businesses or set up satellite campuses, decentralizing services to provide much-needed services and opportunities within communities.

\section{Conclusions and Recommendations}

A key argument of this paper is the IUC concept that can offer the much-needed integrated approach to sustainable, affordable, and accessible solutions to the challenges faced by urban communities in the context of unregulated urbanization syndrome. The innovative concept further argues that its implementation will enhance inclusive urban growth, sustainable housing, and improved service delivery for a healthy and productive urban population. The results are further supported by the correlation between social capital and sustainable development [26]. From the overall research outcome, this paper concludes that the IUC initiative is feasible. The concept adequately accommodates most of the wish list aspirations of the workshops' participants and stakeholders in sync with a smart bottom-up dispensation. If successfully implemented in the case of Okahandja, the IUC ideals could sustainably be replicated in Namibian towns with similar socio-economic and environmental conditions and thus complement the efforts of such government initiatives towards improved quality of lives of the urban population as the Harambee Prosperity Plan, National Development Plan 5 (NDP 5), and Vision 2030. However, the experimental implementation aspect of the IUC concept will require further research. Having thus attempted to provide 
answers to the research questions, the following benefits which are in sync with the smart community paradigm are envisaged:

- Urban land-use densification, in inclusive, interconnected mix-use sustainable housing typologies, commerce, education, community administration, recreation, and social space infrastructure with minimal resources.

- The opportunity for formal and informal commercial activities that could be strictly regulated as in the case of the Post Street Mall in Windhoek.

- Ecological and accessible with attractive landscape and urban furniture.

- The enhancement of the quality of space and visual appreciation stimulate community pride and access.

Finally, it is recommended to organize dissemination workshops through the offices of the responsible Minister of Urban and Rural Development (MURD) to convey the success story of the research on IUC. A strong motivation for further research on the experimental implementation strategies for Okahandja green town with cost implications should be availed to the MURD and the local authorities.

\section{Acknowledgements}

The authors would wish to express profound appreciation to the founder and Chief Executive of the inclusive urban campus and learning environment Dololo, Mr. Tim Wucher. His visionary ideas and support were instrumental to the overall success of the research. Equally appreciated is the contribution through the active participation of Ms. Chantal Claassen and Ms. Disney Andreas, who are both of the Dololo set up. Special gratitude is directed to the Chief Executive Officer, Okahandja Municipality, Mrs. Martha Mutilifa, and her Councilors, and the entire Okahandja communities for their wholesome cooperation during the research. Well-deserved gratitude is channeled to all the stakeholders and workshop participants for their unreserved cooperation. This research would not have been possible without the moral and financial support of the UTA-NUST Partnership Service Agreement. To it, we owe the success of this research project.

\section{Conflicts of Interest}

The authors declare no conflicts of interest regarding the publication of this paper.

\section{References}

[1] World Population Review (2021) Population of Cities in Namibia. https://worldpopulationreview.com/countries/cities/namibia

[2] Magdaniel, F. (2013) The University Campus and Its Urban Development in the Context of the Knowledge Economy. EURA Conference Cities as Seedbeds for Innovation, Enschede, 3-6 July 2013, 17 p.

[3] Charles, D. (2011) The Role of Universities in Building Knowledge Cities in Australia. Built Environment, 37, 281-298. https://doi.org/10.2148/benv.37.3.281 
[4] Den Heijer, A., De Vries, J. and De Jonge, H. (2012) Developing Knowledge Cities: Towards Aligning Urban and Campus Strategies. In: Van Geenhuizen, M. and Nijkamp, P., Eds., Creative Knowledge Cities: Myths, Visions and Realities, Edward Elgar Publishing, Cheltenham, 104-131. https://doi.org/10.4337/9780857932853.00011

[5] Nallathiga, R. (2013) Inclusive Urban Planning and Development through the Earmarking of Land and Housing for the Urban Poor. Proceedings (Technical Papers. Part II) of the 61 st National Town and Country Planners Congress, Ahmedabad, 8-10 February 2013, 1-8. https://doi.org/10.2139/ssrn.2255843

[6] Tvedten, I. and Mupotola, M. (1995) Urbanisation and Urban Policies in Namibia. SSD Discussion Paper 10, Multi-Disciplinary Research Centre, University of Namibia, Windhoek.

[7] Friedman, F. (2000) Deconstructing Windhoek: The Urban Morphology of A Post-Apartheid City. University College London, Development Planning Unit, London.

[8] Indongo, N. (2015) The Effect of Urbanisation on Housing Conditions in Namibia. International Journal of Humanities Social Sciences and Education, 2, 1-8.

[9] GRN (1999) The Constitution of the Republic of Namibia. Government of the Republic of Namibia, Windhoek.

[10] NSA (2019) Namibia Labour Force Survey 2018 Report. Namibia Statistics Agency, Windhoek.

[11] Ministry of Regional and Local Government, Housing and Rural Development (2009) Namibia National Housing Policy. MRLGHRD, Windhoek.

[12] Remmert, D. and Ndhlovu, P. (2018) Housing in Namibia: Rights, Challenges And Opportunities. Research Report: Right to Housing Project. Institute for Public Policy Research (IPPR), Windhoek.

[13] Pouw, N. and Gupta, J. (2016) Inclusive Development: A Multi-Disciplinary Approach. Current Opinion in Environmental Sustainability, 24, 104-108. https://doi.org/10.1016/j.cosust.2016.11.013

[14] Gupta, J., Pouw, N. and Ros-Tonen, M. (2015) Towards an Elaborated Theory of Inclusive Development. European Journal of Development Research, 27, 541-559. https://doi.org/10.1057/ejdr.2015.30

[15] World Bank (2017) Does Fiscal Policy Benefit the Poor and Reduce Inequality in Namibia? World Bank, Washington DC.

[16] Den Heijer, A. (2012) Managing the University Campus: Exploring Models for the Future and Supporting Today's Decisions. Centre for Effective Learning Environments, No. 2012/02, 6 p. https://doi.org/10.1787/5k9b950gh2xx-en

[17] Poph, C. (2008) From Science to Policy through Transdisciplinary Research. Environmental Science \& Policy, 11, 46-53. https://doi.org/10.1016/j.envsci.2007.06.001

[18] Polk, M. (2015) Transdisciplinary Co-Production : Designing and Testing a Transdisciplinary Research Framework for Societal Problem Solving. Futures, 65, 110-122. https://doi.org/10.1016/j.futures.2014.11.001

[19] Cash, D.W., Clark, W.C., Alcock, F., Dickson, N.M., Eckley, N. Guston, D.H., Jäger, J. and Mitchell, R.B. (2003) Knowledge Systems for Sustainable Development. Proceedings of the National Academy of Sciences of the United States of America, 100, 8086-8091. https://doi.org/10.1073/pnas.1231332100

[20] Richardson, T. and Connelly, S. (2005) Reinventing Public Participation: Planning In the Age of Consensus. In: Jones, P., Petrescu, D. and Till, J., Eds., Architecture 
and Participation, Routledge, Abingdon, $28 \mathrm{p}$.

[21] Rezazadeh, M.H., Zehi, F.H. and Rad, R.E. (2016) The Study of Moderating Role of Social Capital in the Relationship between Development of Urban Tourism and Sustainable Urban Development (Case Study: Zahedan). Current Urban Studies, 4, 461-475. https://doi.org/10.4236/cus.2016.44030

[22] Dodig, M.B. and Groat, L.N. (2020) The Routledge Companion to Games in Architecture and Urban Planning: Tools for Design, Teaching, and Research. 1st Edition, Routledge, New York. https://doi.org/10.4324/9780429441325

[23] Warburton, D. (1998) Community and Sustainable Development: Participation in the Future. 1st Edition, Routledge, Abingdon.

[24] Jones, P., Petrescu, D. and Till, J. (2005) Architecture and Participation. 1st Edition, Routledge, Abingdon.

[25] Diallo, A., Yin, Z.H. and Beckline, M. (2017) Assessing the Socio-Economic Impacts of the Informal Sector in Guinea, West Africa. Open Access Library Journal, 4 e3290.

[26] Groat, L.N. and Wang, D. (2013) Architectural Research Methods. John Wiley \& Sons, Hoboken. 